\title{
The Process of People Gold Mining in Paningkaban Village Banyumas Indonesia
}

\author{
Muslihudin Muslihudin ${ }^{1,2,{ }^{*}}$, Azis Nur Bambang ${ }^{3}$, Eko Hendarto ${ }^{4}$, and Thomas Triadi Putranto ${ }^{5}$ \\ ${ }^{1}$ Faculty of Social and Political Sciences, Jenderal Soedirman University, Purwokerto-Indonesia \\ ${ }^{2}$ Doctoral Program of Environmental Sciences, School of Postgraduate Studies, Diponegoro University, Semarang-Indonesia \\ ${ }^{3}$ Faculty of Fisheries and Marine Sciences, Diponegoro University, Semarang-Indonesia \\ ${ }^{4}$ Faculty of Animal, Jenderal Soedirman University, Purwokerto-Indonesia \\ ${ }^{5}$ Geology Department of Technic Faculty, Diponegoro University, Semarang-Indonesia
}

\begin{abstract}
Gold mining in Paningkaban Banyumas conducted by the community is called the People gold mining. At the beginning, many miners from outside the region have involved and transferred of method, technic and knowledge about gold mining to local people. The aim of the study is to identify the existing process of public gold mining. The method of the study is qualitative by using observation and interview. The result showed that the mining process are: 1. Determining the location of mining well; in this determination there are two references; rational and intuition 2. Mining; at this stage, a deep well is drawn about 50-100 meters that leads vertically and horizontally. It is the most high-risk stage because of work accidents that occurred and potentially environment destruction. 3. Pulverization; this stage is classified as the lowest level of difficulty and risk, therefore in this work many woman included. 4. Rolling; in this stage involves enough technology, electrical mechanic and energy with the dynamo and using mercury that potentially contaminate environment. 5. Filtering; this stage is a quite risky because the workers contact directly with mercury. 6. Burning; is the shortest process to separate mercury with gold grains. 7 . Sales to local buyer guided by the international gold market in every Thursday.
\end{abstract}

\section{Introduction}

Mining of natural resources is quite a lot done in Indonesia. This is very reasonable, because the potential that exists in Indonesia is very rich in natural resources. One form that is developing in many areas is gold. The history of gold mining at this time is a new moment coming on the earth archipelago that always exploit the spices, also glance at the mineral wealth. Traces of mining activities undertaken by the Dutch during valid in Indonesia can still be found starting from Sumatra, Java, Kalimantan, and Sulawesi. Mineral mining [1] describes long before the Dutch come, the Indonesia is already well known to be rich in gold.

Gold mining has many variants which include mining that belongs to the traditional category, illegal, small scale, and usually on behalf of the people. Mineral Tambang [1], illustrates that public mining is a mining whose method is applied to underground mining under Gophering method, which is an unsystematic mining method, no need for development works and excavation only following the direction of the ore crops. Therefore the size of the holes (stope) is also indefinite, depending on the size of the ore deposit in that place and generally without good buffering. This mining method is generally without adequate buffers and excavation is generally done without mechanical tools. This method of gold mining is commonly applied in various areas of
Indonesian mining operations, such as in Ciguha, Pongkor-Bogor; Gunung Peti, Cisolok-Sukabumi; Mount Subang, Tanggeung-Cianjur; Cikajang-Garut; Cikidang, Cikotok-Lebak; Cineam-Tasikmalaya; Kokap-Kulonprogo; Selogiri-Wonogiri, and including those in Banyumas.

The simple method in the mining process makes gold mining of this kind very vulnerable to the risk of work accident. Almost in every public gold mining have an accident that killed miners, including in Banyumas district. Jennifer et al [2], illustrates that public gold mining is often accompanied by degradation of environmental quality. $\mathrm{Hg}$ amalgamation not only has a serious impact on miners but also on the environment, especially with regard to the food chain. Work accidents and mine failures such as landslides are also common.

In addition, there are also legal and illegal variants. Illegal mining is unlicensed mining, often abbreviated as PETI [3]. One of the problems that faced by the Department of Energy and Mineral Resources (DESDM) is the rampant illegal mining activities (PETI). The term PETI was originally used for unlicensed gold mining, but in subsequent developments PETI issues not only on gold mining commodities but also applied to unlicensed mining for other minerals either class A, B or C (PP No. 27 Year 1980 About Classification Excavation Materials) which are usually included in small-scale mining.

Factors that encourage increased PETI activities are: 
1. Mining business in general provides relatively high material benefits, because some excavated materials without going through direct processing can be sold.

2. Relatively high demand for the quarry market, especially in areas with high physical development growth.

3. Easy level of exploitation, intended for class C excavation materials.

4. Very short mining periods, some of which are shorter than the length of the licensing process, since most are small-scale mining [4].

This gold mining seems to have tremendous appeal than mining in other fields. This is understandable because the price of gold is very high compared to the price of other mining materials. Gold is still regarded as a reliable investment instrument, especially in the midst of the current unstable global economic situation. Gold could be a safe-haven investment, unlike other instruments that fluctuate quite a lot.

The purpose of this research is to know about the public gold mining process in Banyumas Regency. How this gold mining process is important to know because it can be used as a basis for consideration management or further development so as not to harm miners, communities and the environment.

\section{Research methods}

This study was designed as a qualitative descriptive study, using case studies. Data collection methods are in-depth interviews and documentation. The analytical method used is qualitative analysis [5]. The process of qualitative analysis begins from the collected data is condensed in the form of research findings that are relevant to the writing material, and then presented in a narrative. Condensation and data presentation are two components of analysis performed simultaneously with the data collection process. The next process is the conclusion, which is done after the data collection process, presented, described and then given a logical interpretation.

The final goal of the analysis is to gain some understanding of the focus of this research. The activity of the two components interacts until the correct conclusion is obtained. If the conclusion is inadequate, it is necessary retesting activity that is by searching data again in the field and try to interpret it, thus the activity of analysis with data collection is the process of the cycle until the research is completed.

\section{Result and discussion}

The gold mining in Paningkaban village of Gumelar sub-district of Banyumas Regency is considered as the public mining. Public mining in the sense of doing mining is a non-government or official institution recognized by the government. In other words this kind of activity is illegal. Illegal activities do not have operational standards that can be justified either jurisdictionally or technically and environmentally.

This gold mining process of the people includes the following important stages.

1. Determination of the location of the mine site. In this study, there are two references used by miners, namely rational logic and intuition or on the basis of guidance of spiritual leaders.

2. Mining. In this stage, site-digging is done within 50-100 meters, vertically and horizontally. This mining process is considered to be the most highrisk stage because of work accidents at this stage. Every site always has a kind of standard operating procedure taught by miners from outside of the area who are the majority of Tasikmalaya people. They are famous as miners who know much about the technical knowledge of gold mining. Security standards carried out in mining are:

2.1 Each hole should be made of wooden steger to prevent from landslides and as well as stairs in and out of miners.

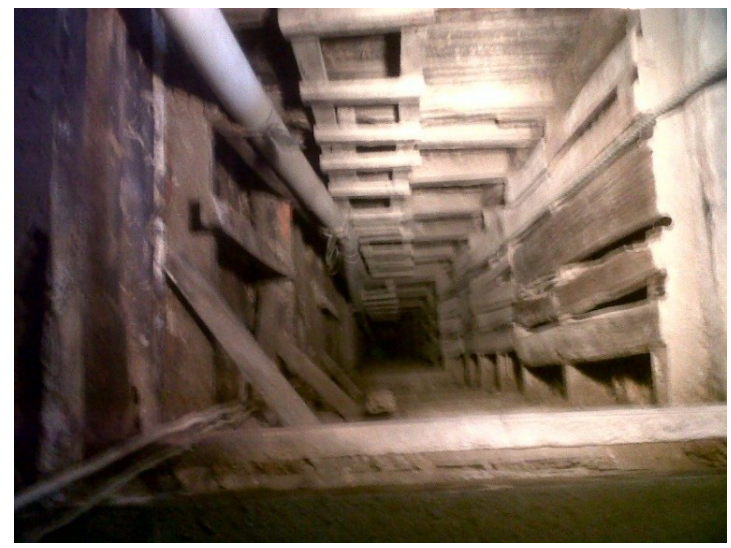

Fig. 1 Mining Site

Figure 1 above is a vertical hole with a relatively sturdy wooden stager installed, as well as a hole that is horizontal. However long it has never been avalanched because the soil type is hard so it is not easy to slide.

2.2 Oxygen filling, this is very important because conditions in deep sites are often filled with acid gases that are very harmful to the miners. Therefore, before the miner enters the well, a blower is inserted into the well by using a compressor through the pipe and fed by electricity. This blower is turned on before the miners enter the hole about 1-2 hours (figure 2 ). This blower function is very important to prevent accident because of the acid gas. Because of the acid gas, miners are banned to do the excavation at night. In addition, the oxygen above the hole is also slightly absorbed by the respiration of plants.

2.3 Lighting, the conditions in the sites are dark, thus the miners need lighting to do their activities. The lighting used is powered by electricity. Therefore if the power is off, then the mine activities automatically stop. 
Electricity energy is quite dominant in the mining process. Electricity is not only used as energy for lighting but also as a dynamo generator in the next process.

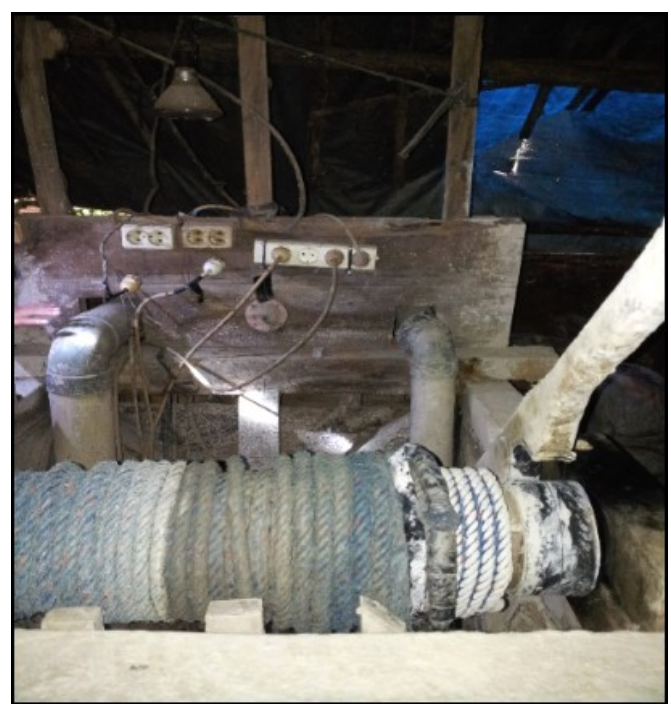

Fig. 2 Electricity and air lines to the site

3. Mining product mashing. This stage is classified as the lowest level of difficulty and risk. That is why women workers are often involved in this work. Ababio et al [6] describes that women are involved in traditional gold mining in Ghana as well. Even in Ghana there are certain signs for women involved in traditional gold mining.

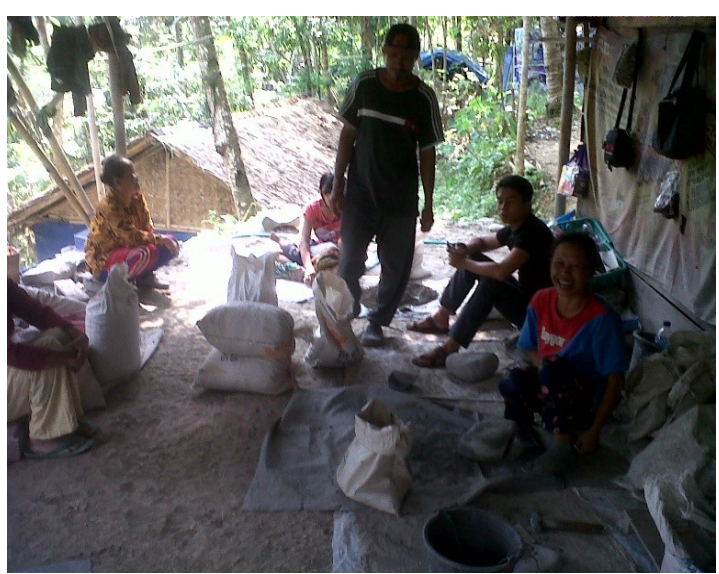

Fig. 3 Women participation in the gold mining

4. Rolling, in this stage is a sufficient work related to technology. The technology used in the mechanical roll that turns the logs using the electrical energy with the dynamo which then rotate the log. This stage also uses chemical liquid called mercury. Mercury is used to tie the existing gold in the log. Rolling for about 3 hours. After the first 2 hours, a bottle of mercury is poured for each drum. Then, the mercury is rolled again for about 1 hour. After that the drums are opened and spilled which then flowed into the tub / pond shelter and some also flow into the river. Then, the content of the bucket which is processed further filtering. On the other hand $[7,8]$ concluded that the gold mining in Gumelar in general has polluted the environment that $\mathrm{Hg}$ levels spread over the Tajum River with values exceeding the environmental quality standard that is $0.002 \mathrm{mg} /$ liter.

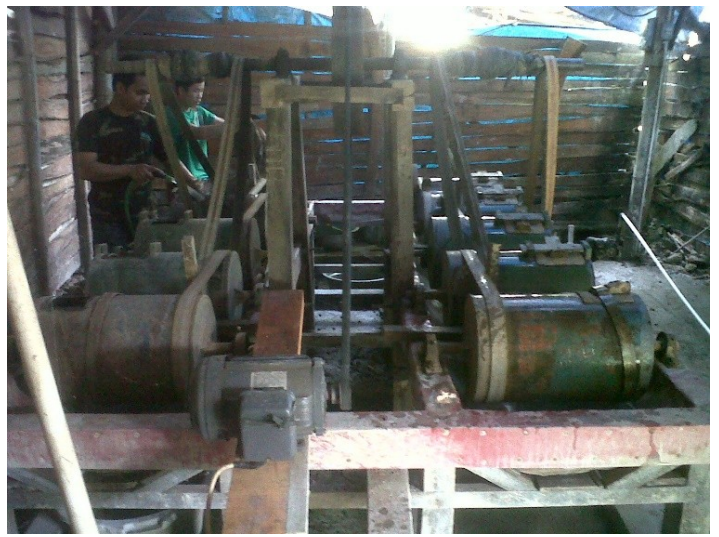

Fig. 4 Rolling

5. Filtering, this stage is a phase that is quite risky because workers directly in contact with mercurycontaining fluid. Filtering is done by bare hands using a soft cloth. Although miners are daily in direct contact with mercury, they do not feel threatened by their health.

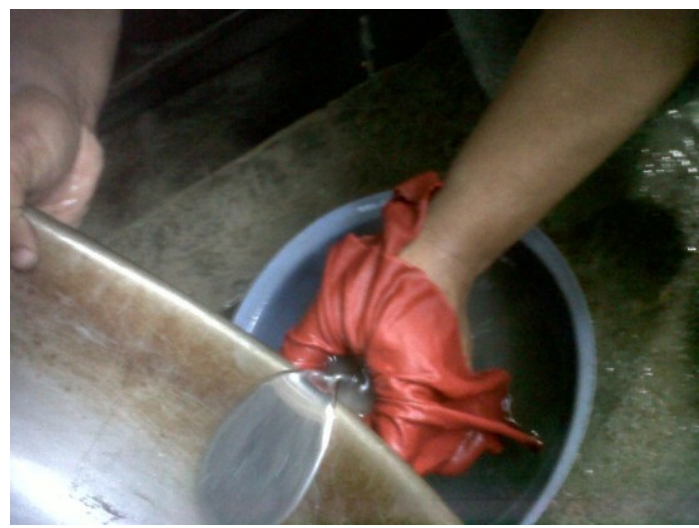

Fig. 5 Filter of fluids containing gold

6. Combustion. Combustion is a relatively short stage to separate the mercury with gold grains. Combustion is using gasoline with a welding tool which is then directed to a lump of gold that is still mixed with mercury. The workers were not using any safeguards. Thus, they are very likely to be contaminated with air from combustion containing mercury. The result of this burning so a golden blob whose color is still whitish and has hardened. In this combustion phase, there is shrinkage of about 50 percent of the previous weight. The gold content of this combustion is about 70 percent, which is usually used as gold jewelry. 


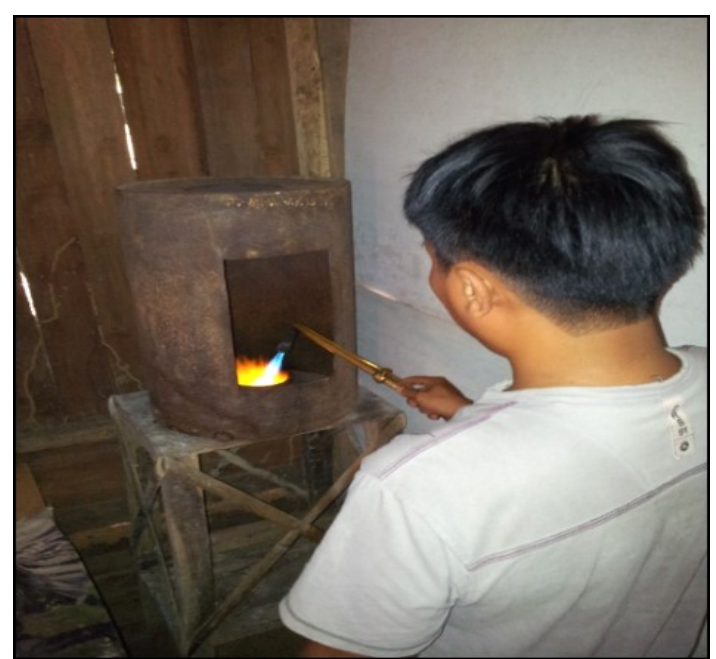

Fig. 6 Separation of mercury with gold grains

7. Selling, this stage is the stage of gaining the economic value of the gold itself. The gold price follows the international price. Although gold mining areas including rural areas even somewhat remote, but the price of gold always follow the real price in international markets that are known through the internet. The price of gold when this research is done is Rp380.000, - / gram. Sales are done every Thursday, as a weekend day because Friday is a holiday. On Thursday was also the result of a mine within a week known. Acceptance of results by miners is accepted. As an illustration of mining products for the present condition that is classified as being low. One log of $4 / 5$ drums a week can be one gold item as shown in the following figure.

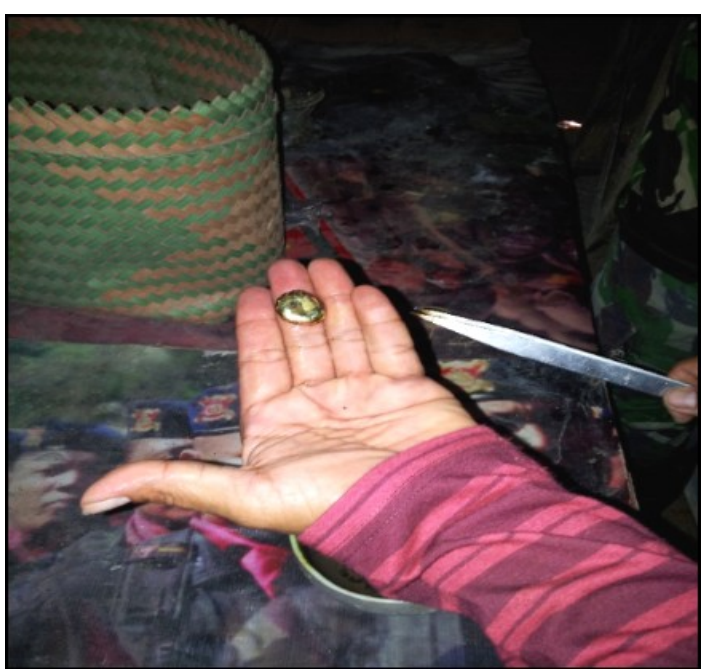

Fig. 7 Sample of ready-to-sell mining products

The weight of gold in the image is about 14.5 grams. The gold content of the time was $70 \%$ (percent), sold at Rp 380.000, - per/gram. Thus, the money earned is $\mathrm{Rp} 5.510 .000$, - (five million five hundred and ten thousand rupiah). Alfonsus et al [9] describes that traditional gold mining has a positive impact on the people's economy so that they also have a positive perception of the mining activity, despite the fact that there is a negative impact on the environment.

\section{Conclusions}

The public gold mining in Gumelar Banyumas Subdistrict is a gold mine that involves a lot of energy. People's gold mining is sustained by the labor of the local population. At first this mining is mostly done by personnel from outside the region. As mining proceeds, there is a process of knowledge transfer from migrants to local residents so that many of the local people are good already at doing their own mining. The gold mining process is quite long and very risky for the safety and health of workers. The most risk-bearing job is excavation into a deep site that can reach hundreds of meters deep. At this stage of the excavation, there are a lot of work accidents. The filtering and combustion phase are also dangerous in which both workers are in direct contact with mercury. Contamination of mercury to the environment is also indicated to have occurred. On that basis the central government through BPPT (Agency for the Assessment and Application of Technology) in collaboration with ESDM (Institution of Energy and Mineral Resources) and the Department of Environment and the Health Office is trying to find the alternative technology that can minimize mercury pollution to the environment.

\section{Suggestions}

The security efforts of miners should be improved so as to minimize / eliminate the number of victims of work accident. The government is still needed to monitor the gold mining conditions of the people even though their status is illegal. However, these activities are very helpful to the community's economy, not only in the villages where there are mining activities but also to the wider community.

\section{Acknowledgements}

Thank to the head of Paningkaban Village, Mr. Sukarmo who has given permission and much information about various matters relating to gold mining in his region. Thank you also to the gold miners of the people who have provided information related to their activities.

\section{References}

1. Mineral of Mining, Jakarta, (2013) http: //www.tambang-penambang-emas, [accessed on April 15, 2015].

2. H. Jennifer, M. Marcello, Tadeu C. Veiga, International Journal of Cleaner Production, Vancouver, Canada, (2003) 
3. Refles, Mining Activities of the People's Peoples and Its Implications on Socio-Economic Condition of the Community In Kenagarian Mundam Sakti Sub-district Nagari, Sijunjung Regency, Andalas University, Padang, (2012)

4. F. Irna, Ismadi and H.S. Dewi, Public Health, Andalas University, Padang, (2010)

5. B.M. Miles, M. Huberman, and J. Saldana, Third Edition Copyright Sage Publications, Inc, Washington, (2014)

6. Ababio E, OFOSU M, 2010, Nordic Journal of African Studies 19(2): 124-147, University of Ghana, Ghana, (2010)
7. Fahmi, Budianta and Idrus, Impact of Mercury Pollution on Geological Media at the People's Mining in Banyumas, Central Java. Proceedings of the 7 th National Geological Engineering Seminar, Faculty of Engineering, Gadjah Mada University, Yogyakarta, (2014)

8. S. Widiadi, Postgraduate Program, Jenderal Soedirman University, Purwokerto, (2013)

9. Alfonsus, H. Harianja and S. Asep, Forest Research Institute, Aek Nauli, Medan, (2014) 